\section{Yield, Fruit Quality Traits, and Leaf Nutrient Concentration of 'Prolific' Sapodilla Grafted onto Seedlings of 16 Sapodilla Rootstocks in Puerto Rico}

\author{
Ricardo Goenaga ${ }^{1,5}$, Heber Irizarry ${ }^{1,3}$, David Jenkins ${ }^{1,4}$, \\ Debbie Boykin ${ }^{2}$, and Angel Marrero ${ }^{1}$
}

ADDITIONAL INDEX wORDs. tropical horticulture, tropical fruits, soluble solids concentration, Manilkara zapota

SUMMARY. Research on sapodilla (Manilkara zapota) has been very limited. A field study was conducted to determine the yield potential, fruit quality traits, leaf nutrient composition, and scion/rootstock compatibility of 'Prolific' sapodilla grafted onto 16 sapodilla rootstock seedlings. For this purpose, seedlings (maternal half-sibs) of cultivars Adelaide, Arcilago, Aruz, Blackwood, Blocksberg, Guilbe, Hanna, Jamaica-1, Larsen, Mendigo-1, Gallera, Morning Star, Russel, Prolific, Timothe, and Vasallo-1 were used as rootstock seedlings and evaluated during 7 years of production at Isabela, PR. Year showed a significant effect on the number of fruit per hectare, yield, individual fruit weight, fruit length and diameter, and total soluble solids. Rootstock seedlings had a significant effect on the number of fruit per hectare, yield, and individual fruit weight but had no effect on other fruit traits. The year $\times$ rootstock interaction was not significant for any of the variables measured in the study. Rootstock seedlings 'Timothe', 'Vasallo-1', 'Larsen', and 'Aruz' had the highest 7-year mean for number and the yield of fruit averaging $4479 \mathrm{fruit} / \mathrm{ha}$ and $1245 \mathrm{~kg} \cdot \mathrm{ha}^{-1}$, respectively. 'Timothe' and 'Vasallo-1' significantly out yielded the 'Prolific' rootstock seedling. The number of fruit per hectare and corresponding yield obtained in this study were very low probably as the result of wind exposure, the presence of the fungus Pestalotia causing floral necrosis, or both. Scion/rootstock incompatibility was not the cause of the low yield performance of grafted trees. The average individual weight of fruit was $282 \mathrm{~g}$ and ranged from 264 to $303 \mathrm{~g}$. Averaged over rootstock seedlings, leaf tissue nutrient concentration did not vary greatly over time. Moreover, tissue nutrient concentration was similar before and after fertilization events.

S apodilla is a member of the Sapotaceae family and is native to southern Mexico and Central America. The sapodilla is not strictly tropical as it can withstand freezing temperatures for several hours. It thrives well on sandy, clay, organic, or calcareous soils and is reputed to be

We thank Pablo Rios and Tomas Miranda for their excellent field assistance.

Mention of trade names or commercial products in this publication is solely for the purpose of providing specific information and does not imply recommendation or endorsement of the U.S. Department of Agriculture.

${ }^{1}$ U.S. Department of Agriculture, Agricultural Research Service, Tropical Agriculture Research Station, 2200 P.A. Campos Avenue, Suite 201, Mayagüez, PR 00680

${ }^{2}$ USDA-ARS, Southeast Area, P.O. Box 225, Stoneville, MS 38776

${ }^{3}$ Retired

${ }^{4}$ Currently at South Carolina Forestry Commission, P.O. Box 21707, Columbia, SC 29221

${ }^{5}$ Corresponding author. E-mail: ricardo.goenaga@ars. usda.gov.

doi: 10.21273/HORTTECH03718-17 drought tolerant (California Rare Fruit Growers, 1996; Morton, 1987). There are about 13 cultivars identified with commercial potential for Florida (Campbell and Ledesma, 2002; Crane and Balerdi, 2005). Two of these cultivars, Prolific and Russell, have been evaluated in the semiarid coast of Puerto Rico for yield, chemical composition, and flavor (VelezColon et al., 1989).

Recommended plant spacing for commercial production is $25 \mathrm{ft}$ apart within a row and $15 \mathrm{ft}$ between rows, about 330 trees/ha (Crane and Balerdi, 2005). The fertilizer recommendation for 8-year-old bearing trees is $800 \mathrm{~g}$ of nitrogen $(\mathrm{N}), 175 \mathrm{~g}$ of phosphorous (P), and $200 \mathrm{~g}$ of potassium $(\mathrm{K})$ per year. Studies have shown that Thai cultivars respond well to pruning but those from Tropical America responded poorly (Wasielewski and Campbell, 1999). Some cultivars fruit year-round. The fruit reaches maturity at 4-6 months after tree flowering. During a 4 -year experimental harvest cycle conducted at the semiarid region of Puerto Rico, trees of 'Larsen', 'Russel', and 'Prolific' yielded 205, 175, and $91 \mathrm{~kg}$ of marketable fruit/tree per year, respectively (Velez-Colon et al., 1989). In Venezuela, Quijada et al. (2005) evaluated three, 8-10-year-old sapodilla cultivars grafted onto a Criollo rootstock during a 3-year harvest cycle. Tree yield as high as $436 \mathrm{~kg} /$ tree per year was reported; however, the authors found large variability in fruit production averaging $271 \%$ within the same cultivars and $872 \%$ between cultivars during the harvest cycle. Mature sapodilla fruit will ripen in 5-10 d at room temperature. The shelf life can be extended to about $15 \mathrm{~d}$ if the fruit is ripened at $20{ }^{\circ} \mathrm{C}$. Treatment of fruit with 1-methylcyclopropene (1-MCP) at $100 \mathrm{~nL} \cdot \mathrm{L}^{-1}$ resulted in a shelf life of $38 \mathrm{~d}$ at $14^{\circ} \mathrm{C}$ (Arevalo et al., 2007). The most reliable method of propagation is by grafting but because of the profuse

\begin{tabular}{llll}
\hline $\begin{array}{l}\text { Units } \\
\text { To convert U.S. to SI, } \\
\text { multiply by }\end{array}$ & U.S. unit & SI unit & $\begin{array}{l}\text { To convert SI to U.S., } \\
\text { multiply by }\end{array}$ \\
\hline 0.4047 & acre $(\mathrm{s})$ & $\mathrm{ha}$ & 2.4711 \\
29.5735 & $\mathrm{fl} \mathrm{oz}$ & $\mathrm{mL}$ & 0.0338 \\
0.3048 & $\mathrm{ft}$ & $\mathrm{m}$ & 3.2808 \\
3.7854 & $\mathrm{gal}$ & $\mathrm{L}$ & 0.2642 \\
2.54 & inch $(\mathrm{es})$ & $\mathrm{cm}$ & 0.3937 \\
25.4 & inch $(\mathrm{es})$ & $\mathrm{mm}$ & 0.0394 \\
0.4536 & $\mathrm{lb}$ & $\mathrm{kg}$ & 2.2046 \\
1.1209 & $\mathrm{lb} / \mathrm{acre}$ & $\mathrm{kg} \cdot \mathrm{ha}^{-1}$ & 0.8922 \\
1.6093 & $\mathrm{mph}$ & $\mathrm{km} \cdot \mathrm{h}^{-1}$ & 0.6214 \\
28.3495 & $\mathrm{oz}$ & $\mathrm{g}$ & 0.0353 \\
1 & $\mathrm{ppb}$ & $\mathrm{nL} \cdot \mathrm{L}^{-1}$ & 1 \\
1 & $\mathrm{ppm}$ & $\mathrm{mg} \cdot \mathrm{kg}^{-1}$ & 1 \\
1 & $\mathrm{ppm}$ & $\mu \mathrm{g} \cdot \mathrm{g}^{-1}$ & 1 \\
6.8948 & $\mathrm{psi}$ & $\mathrm{kPa}$ & 0.1450 \\
$\left({ }^{\circ} \mathrm{F}-32\right) \div 1.8$ & ${ }^{\circ} \mathrm{F}$ & ${ }^{\circ} \mathrm{C}$ & $\left({ }^{\circ} \mathrm{C} \times 1.8\right)+32$
\end{tabular}


exudation of gummy latex the method is cumbersome. In Florida, budding, cleft, and side-veneer grafting techniques have been implemented with moderate success. Vegetative propagation promotes tree dwarfing, early bearing, and increase in yield (Morton, 1987). Little research has been conducted to evaluate sapodilla rootstocks. The objective of this work was to evaluate 16 sapodilla rootstock seedlings for fruit quality traits, scion/rootstock compatibility, and tissue nutrient concentration.

\section{Materials and methods}

This study was conducted in Puerto Rico at the U.S. Department of Agriculture, Agricultural Research Service Research Farm in Isabela (Coto clay: clayey, kaolinitic isohyperthermic Typic Hapludox). The soil has a $\mathrm{pH}$ of $7.03,29.8 \mathrm{mg} \cdot \mathrm{kg}^{-1}$ ammonium- $\mathrm{N}\left(\mathrm{NH}_{4}-\mathrm{N}\right), 14.0 \mathrm{mg} \cdot \mathrm{kg}^{-1}$ nitrate- $\mathrm{N}\left(\mathrm{NO}_{3}-\mathrm{N}\right), 21.0 \mathrm{mg} \cdot \mathrm{kg}^{-1} \mathrm{P}$, $570 \mathrm{mg} \cdot \mathrm{kg}^{-1} \mathrm{~K}, 431 \mathrm{mg} \cdot \mathrm{kg}^{-1}$ calcium (Ca), $219 \mathrm{mg} \cdot \mathrm{kg}^{-1}$ magnesium $(\mathrm{Mg})$, $107 \mathrm{mg} \cdot \mathrm{kg}^{-1}$ iron $(\mathrm{Fe}), 5 \mathrm{l} \mathrm{mg} \cdot \mathrm{kg}^{-1}$ manganese $(\mathrm{Mn}), 6.1 \mathrm{mg} \cdot \mathrm{kg}^{-1}$ zinc $(\mathrm{Zn})$, and $1.94 \%$ organic carbon. The 93-year (1919-2012) mean annual rainfall is $1649 \mathrm{~mm}$ and Class A pan evaporation is $1672 \mathrm{~mm}$. Mean monthly maximum and minimum temperatures are 29.8 and $19.9{ }^{\circ} \mathrm{C}$. Soil samples were taken 2 months before planting by taking 15 borings at a depth of $0-25 \mathrm{~cm}$ from each of the projected tree rows. Samples were air-dried and passed through a 20 -mesh screen. Soil $\mathrm{pH}$ in water and $0.01 \mathrm{M}$ calcium chloride ( 1 soil : 2 water) were measured with a glass electrode. Exchangeable cations (K, $\mathrm{Mg}$, and $\mathrm{Ca}$ ) were extracted with neutral $\mathrm{l} \mathrm{N}$ ammonium acetate and determined by atomic absorption spectroscopy (Sumner and Miller, 2007). Phosphorus was extracted with $1 \mathrm{~N}$ ammonium fluoride and $0.5 \mathrm{~N}$ hydrochloric acid $(\mathrm{HCl})$ and determined using the ascorbic acid method (Benton, 2001). Organic carbon was determined by the Walkley-Black method (Nelson and Sommers, 2007). Soil ammonium and nitrate were determined by steam distillation (Mulvaney, 2007).

Scionwood obtained from a single 'Prolific' tree was side-veneer grafted onto open-pollinated seedlings (maternal half-sibs) rootstocks of 'Adelaide', 'Arcilago', 'Aruz', 'Blackwood', 'Blocksberg', 'Guilbe', 'Hanna', 'Jamaica-1', 'Larsen', 'Mendigo-1', 'Gallera', 'Morning Star', 'Russel', 'Prolific', 'Timothe', and 'Vasallo-l'. These introduced or locally selected sapodilla materials were obtained from the germplasm collection of the University of Puerto Rico Agricultural Experiment Station, Juana Diaz, PR.

Six-month-old grafted trees were transplanted to the field on 2 May 2001 . Trees of the 16 rootstock seedlings were arranged in a randomized complete-block design with four replications. Before transplanting, the soil was chisel-plowed to a depth of about $90 \mathrm{~cm}$. Planting holes about 1.5 -ft deep were dug with an auger connected by a drive shaft to the power-take-off unit of a tractor. On transplanting, each tree received $11 \mathrm{~g}$ granular $\mathrm{P}$ provided in the form of triple superphosphate.

Within a replication, plots for each treatment (rootstock seedlings) contained two trees spaced $20 \mathrm{ft}$ apart and $30 \mathrm{ft}$ between adjacent rows (179 trees/ha) in a triangular array. The experiment was surrounded by a guard row of 'Prolific' seedlings. Irrigation was provided with spinner jets (model DXMAG368X; Maxijet, Dundee, FL) spaced $20 \mathrm{ft}$ apart and providing $13.5 \mathrm{gal} / \mathrm{h}$ at $20 \mathrm{psi}$ when the soil water tension at a depth of $30 \mathrm{~cm}$ exceeded $50 \mathrm{kPa}$. Fertilization was provided every 3 months using a $15 \mathrm{~N}-2.2 \mathrm{P}-16.3 \mathrm{~K}-1.8 \mathrm{Mg}$ commercial mixture by applying $350 \mathrm{~g}$ of fertilizer per plant from 2001 to $2005,500 \mathrm{~g}$ from 2006 to 2008 , and $1000 \mathrm{~g}$ from 2009 to 2012. Herbicide (glyphosate) for weed control was applied only in strips within the planting row. Weeds between rows were controlled with a tractor mower. Oil spray (Saf-T-Side; Brandt Consolidated, Springfield, IL) was occasionally used during rainy periods to control sooty mold.

Beginning in Mar. 2010 until Dec. 2012, about four mature leaves taken around the tree canopy from the third node were collected from all treatment trees and composited for each treatment (rootstock seedling) to assess tree nutrition. For this purpose, leaves were ground using a Wiley mill (No. I; Arthur H. Thomas Co., Philadelphia, PA) and analyzed for $\mathrm{N}, \mathrm{P}, \mathrm{K}, \mathrm{Ca}, \mathrm{Mg}, \mathrm{Fe}, \mathrm{Mn}$, $\mathrm{Zn}$, and boron (B) concentration using recommended digestion procedures (Perkin-Elmer, 1994). For this purpose, leaf samples were incinerated in crucibles at $500{ }^{\circ} \mathrm{C}$ for 4 $\mathrm{h}$ and allowed to cool overnight. The incinerated samples were digested with $20 \mathrm{~mL}$ of $33 \% \mathrm{HCl}$ acid until $10 \mathrm{~mL}$ of solution remained in the crucible. After digestion was completed, each sample was filtered through Whatman No. 541 filter paper (GE Healthcare Life Sciences, Buckingham, United Kingdom) into a $100-\mathrm{mL}$ volumetric flask. The solution was used for nutrient determination using an inductively coupled plasma-optical emission spectrometer (PE 7300DV; Perkin-Elmer, Shelton, CT). Total $\mathrm{N}$ was determined by a modification of the micro-Kjeldahl method (Foss Tecator, 2002). For this purpose, $0.2 \mathrm{~g}$ of tissue was weighed and transferred to a Kjeldahl tube. The following compounds were added to each tube: $6 \mathrm{~mm}$ Hengar granules (Fisher Scientific, Fair Lawn, NJ) for smooth boiling, one catalyzing tablet ( $1.5 \mathrm{~g}$ potassium sulfate + $0.15 \mathrm{~g}$ copper sulfate), $5 \mathrm{~mL}$ of concentrated sulfuric acid, and $3 \mathrm{~mL}$ of $30 \%$ hydrogen peroxide. Samples were digested in a digestion block for $2 \mathrm{~h}$ at $380^{\circ} \mathrm{C}$.

Harvests were initiated in Apr. 2006. At this time, grafted trees were about 5.5 years old. At harvest, fruit were cut either manually or with telescopic long reach pruners (model 160ZR-3.0-5; ARS Corp, Osaka, Japan). Representative fruit totaling $10 \%$ of those harvested were used to determine the fruit diameter and fruit length as well as soluble solids with a temperature-compensated digital refractometer (Packet PAL-1; ATAGO, Tokyo, Japan) about $5 \mathrm{~d}$ after harvest. The fruit length and diameter were measured with a caliper. Diameter was measured on the equatorial section of the fruit and length from the proximal to the distal end. Flowering normally occurred during April to November and fruit harvested from February to July peaking in March, April, and May. After a 7-year harvesting period, the experiment was ended in Dec. 2012. At this time, compatibility between scion and rootstock seedling was assessed using a compatibility rating based on the degree of deformity at the 
scion-rootstock junction at the grafted area. Treatment trees were given an overall compatibility rating as follows: 1 = no deformity, $2=$ slight deformity, 3 = moderate deformity, $4=$ marked deformity, and $5=$ severe deformity.

Analysis of variance was carried using the GLM procedure of SAS (release 9.4 for Windows; SAS Institute, Cary, NC). After significant F test at $P \leq 0.05$, mean separation was performed with the Tukey's honest significant difference range test.

\section{Results and discussion}

The year $\times$ rootstock interaction was not significant for any of the variables measured in the study. However, year and rootstock seedlings had a significant effect $(P \leq 0.01)$ on the number of fruit per hectare, yield, and individual fruit weight. Year had a significant effect on fruit length, diameter, and total soluble solids, but rootstock seedlings had no effect on these fruit traits. Compatibility between scion and rootstock seedling made at the end of the experimental period was significant (Table 1).
As expected, trees exhibited an overall increase in the number of fruit produced during the first $4-5$ years of production as trees increased in age (Table 2). The magnitude of this response was similar among rootstock seedlings as noted by the lack of a significant year $\times$ rootstock interaction (Table 1 ). It is noteworthy that at the end of the 7-year harvest cycle, fruit production of trees grafted onto 'Morning Star' was exactly the same as the average production, 1009 fruit/ha (Table 2).

There were no significant differences in the number of fruit per hectare and yield when scionwood of 'Prolific' was grafted onto rootstock seedlings of 'Timothe', 'Vasallo-1', 'Larsen', and 'Aruz'. During the 7-year harvest cycle 'Prolific' grafted onto these rootstock seedlings averaged 4479 fruit/ha equivalent to $1245 \mathrm{~kg} \cdot \mathrm{ha}^{-1}$. When 'Prolific' was grafted onto itself, production only averaged 2235 fruit/ha corresponding to $667 \mathrm{~kg} \cdot \mathrm{ha}^{-1}$ or about a $50 \%$ reduction in yield. Among the four most promising rootstock seedlings, only the local selections 'Timothe' and 'Vasallo-1' significantly out yielded the rootstock seedling 'Prolific' (Tables 1 and 2). 'Morning Star' had the lowest 7-year mean for the number of fruit and yield although values for this rootstock seedling were not significantly different from those obtained for many of the other rootstock seedlings (Table 1). The number of fruit per hectare and corresponding yield obtained in this study were very low (Table 1 ). Although not supported with experimental data from replicated experiments, Balerdi and Shaw (1998) reported that some sapodilla cultivars are capable of producing 90-200 kg of fruit per tree. Velez-Colon et al. (1989) reported tree yield of 103 $\mathrm{kg} /$ tree per year for cultivar Prolific; however, data from this experiment were not statistically analyzed by the authors because of the large variability found in their experimental data. A possible explanation for the low yield and fruit number found in this study could have been the result of the experiment being located in a very windy area of the research farm. In fact, the number of fruit produced in the most exposed areas of the experiment (replications 2 and 3) was 39\%

Table 1. Yield and fruit quality traits of 'Prolific' sapodilla grafted onto seedlings of 16 sapodilla rootstocks planted in Puerto Rico. Values are means of four replications and 7 years (2006-12).

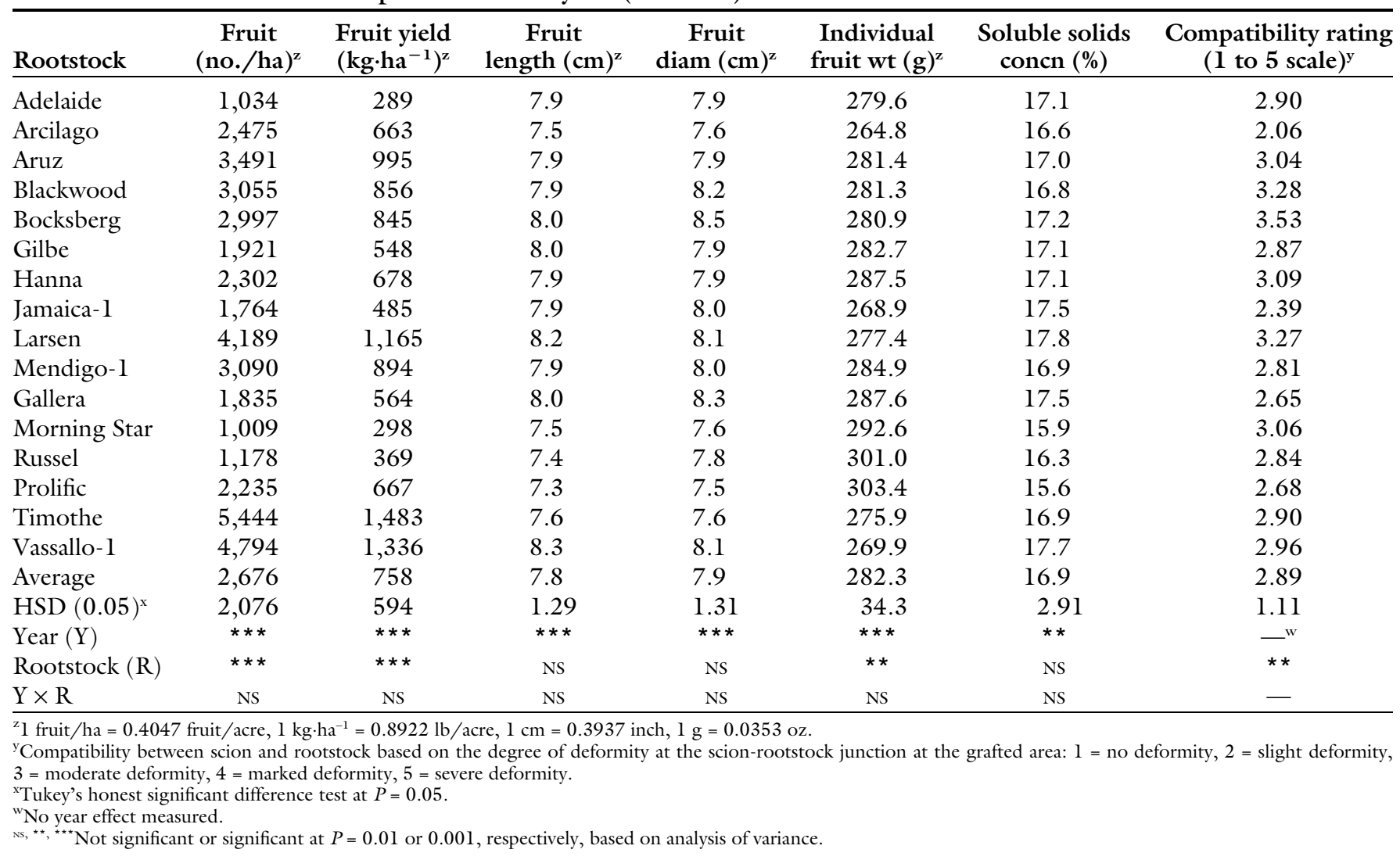


Table 2. Yearly fruit production of 'Prolific' sapodilla grafted onto seedlings of 16 sapodilla rootstocks. Values are means of four replications.

\begin{tabular}{|c|c|c|c|c|c|c|c|c|}
\hline \multicolumn{9}{|c|}{ Fruit $(\text { no. } / \text { ha })^{\mathrm{z}}$} \\
\hline Rootstock & Mean production & 2006 & 2007 & 2008 & 2009 & 2010 & 2011 & 2012 \\
\hline Adelaide & 1,034 & 179 & 538 & 964 & 1,412 & 1,614 & 1,076 & 1,457 \\
\hline Aruz & 3,491 & 672 & 2,286 & 3,430 & 4,573 & 5,290 & 3,587 & 4,595 \\
\hline Blackwood & 3,055 & 381 & 1,345 & 2,533 & 4,035 & 4,102 & 3,878 & 5,111 \\
\hline Bocksberg & 2,997 & 291 & 874 & 2,712 & 3,519 & 4,842 & 3,901 & 4,842 \\
\hline Jamaica-1 & 1,764 & 157 & 1,233 & 1,816 & 2,040 & 2,825 & 1,883 & 2,399 \\
\hline Larsen & 4,189 & 852 & 1,592 & 3,833 & 5,111 & 6,837 & 5,201 & 5,896 \\
\hline Mendigo-1 & 3,090 & 538 & 1,726 & 2,399 & 4,595 & 4,394 & 4,080 & 3,901 \\
\hline Gallera & 1,835 & 403 & 1,345 & 1,367 & 2,309 & 3,094 & 1,659 & 2,668 \\
\hline Morning Star & 1,009 & 45 & 628 & 1,098 & 1,435 & 2,018 & 829 & 1,009 \\
\hline $\mathrm{HSD}^{\mathrm{y}}$ & 2,076 & 1,408 & 2,564 & 4,270 & 5,876 & 7,574 & 6,914 & 8,134 \\
\hline
\end{tabular}

${ }^{\mathrm{z}} 1$ fruit/ha $=0.4047$ fruit/acre.

${ }^{\text {y}}$ Tukey's honest significant difference test at $P=0.05$.

lower than in less exposed areas (replications 1 and 4). Flight activity of honeybees (Apis mellifera) and the main pollinator of sapodilla decreases with increasing wind speed (Winston, 1987). In avocado (Persea americana) and blueberry (Vaccinium corymbosum), wind speeds greater than $15-16 \mathrm{~km} \cdot \mathrm{h}^{-1}(9.3-9.9 \mathrm{mph})$ reduce bee activity (Dixon, 2004; Tuell and Isaacs, 2010). In our experiment, average daily wind speed was 5.1 $\mathrm{mph}$, but the average maximum wind speed, which normally occurs during the day when bees are active, was 18.1 $\mathrm{mph}$. This high wind speed may have reduced bee foraging and consequently pollination. Growers may consider locating sapodilla orchards in areas not exposed to high winds. Also and perhaps compounding the wind effect, the collection of flower samples demonstrated the presence of the fungus Pestalotia. This fungus is known to cause floral necrosis and a reduction in orchard productivity of mamey sapote (Pouteria sapota), a close relative of sapodilla (Vasquez-Lopez et al., 2012). Although tree size was not measured, the authors estimate that tree height and canopy width did not exceed 13 and $16 \mathrm{ft}$, respectively, at the end of the experimental period. Therefore, the authors suggest that using a higher tree density, perhaps $20 \mathrm{ft}$ between trees and $20 \mathrm{ft}$ between rows (269 trees/ha) in a triangular array, is totally feasible to increase yield per acre. Crane and Balerdi (2015) recommend minimum planting distances for sapodilla of $25 \times 15 \mathrm{ft}, 25 \times 20 \mathrm{ft}$, or 25 $\times 25 \mathrm{ft}$. A distance of $20 \times 20 \mathrm{ft}$ has been used with great success at two locations in orchards of mamey sapote which grows to a similar size as grafted sapodilla (Goenaga and Jenkins, 2012).

Individual weight of fruit averaged over rootstock seedlings was $282.3 \mathrm{~g}$ (Table 1). This weight is consistent with fruit graded as medium-large (Balerdi et al., 2013). The highest individual fruit weight (303.4 g) was produced by 'Prolific' (grafted onto itself), but this value was not significantly higher than that obtained for other rootstock seedlings except for 'Jamaica-1' and 'Arcilago' which averaged significantly lower individual fruit weight $(266.8 \mathrm{~g})$. There were no significant rootstock seedling effects on fruit length and diameter; therefore, higher individual fruit weight obtained by 'Prolific' over 'Jamaica1 ' and 'Arcilago' could not be attributed to these fruit traits (Table 1). Rootstock seedlings did not have a significant effect on soluble solids concentration, which averaged $16.9 \%$ (Table 1). There are few reports on soluble solid concentration values of sapodilla cultivars. Shende (1993) reports soluble solids values ranging from $23.8 \%$ to $24.1 \%$ in cultivar Kalipatti. Kader (2009) reported values between 13\% and $26 \%$ in sapotes in general. VelezColon et al. (1989) reported average soluble solid concentration of $18.5 \%$ for 'Prolific'.

There were significant differences in rootstock-scion compatibility (Table 1 ). The highest value (3.53) corresponding to "moderate deformity" between scion and rootstock seedling was obtained in 'Bocksberg'. The lowest value (2.23) corresponding to "slight deformity" was obtained in rootstock seedling 'Jamaica-1' and 'Arcilago'; however, these were not significantly different from most other rootstock seedlings suggesting that they are not necessarily more suited for commercial propagation. None of the 16 rootstock seedlings received a rating of 4.0 or higher indicating a "marked or severe deformity". Fifteen of the 16 rootstock seedlings used in this study had a compatibility value between 2 and 3 (slight to moderate deformity) but these included both, high and low yielders. Therefore, the authors conclude that scion-rootstock compatibility is not the cause of the overall low yield performance of trees in this study.

Averaged over rootstock seedlings, the leaf tissue nutrient concentration of major elements $(\mathrm{N}, \mathrm{P}, \mathrm{K}$, 
$\mathrm{Ca}$, and $\mathrm{Mg}$ ) in 'Prolific' trees grafted onto the 16 rootstock seedlings did not vary greatly over time. Moreover, tissue nutrient concentration was similar before and after fertilization events (Fig. IA and B). During the 33-month leaf-sampling period for nutrient analyses, average leaf $\mathrm{N}$ concentration ranged from $1.26 \%$ to

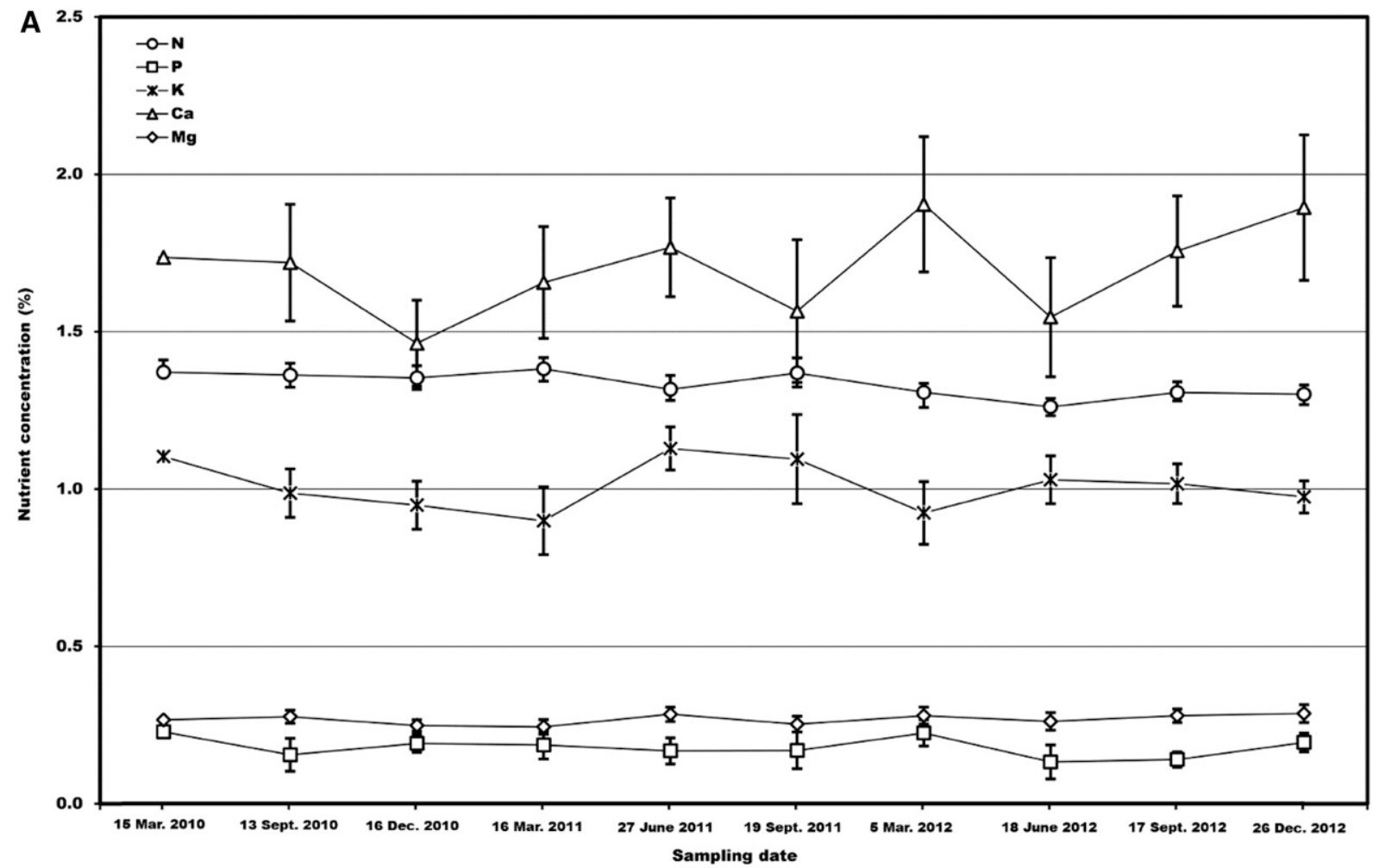

B

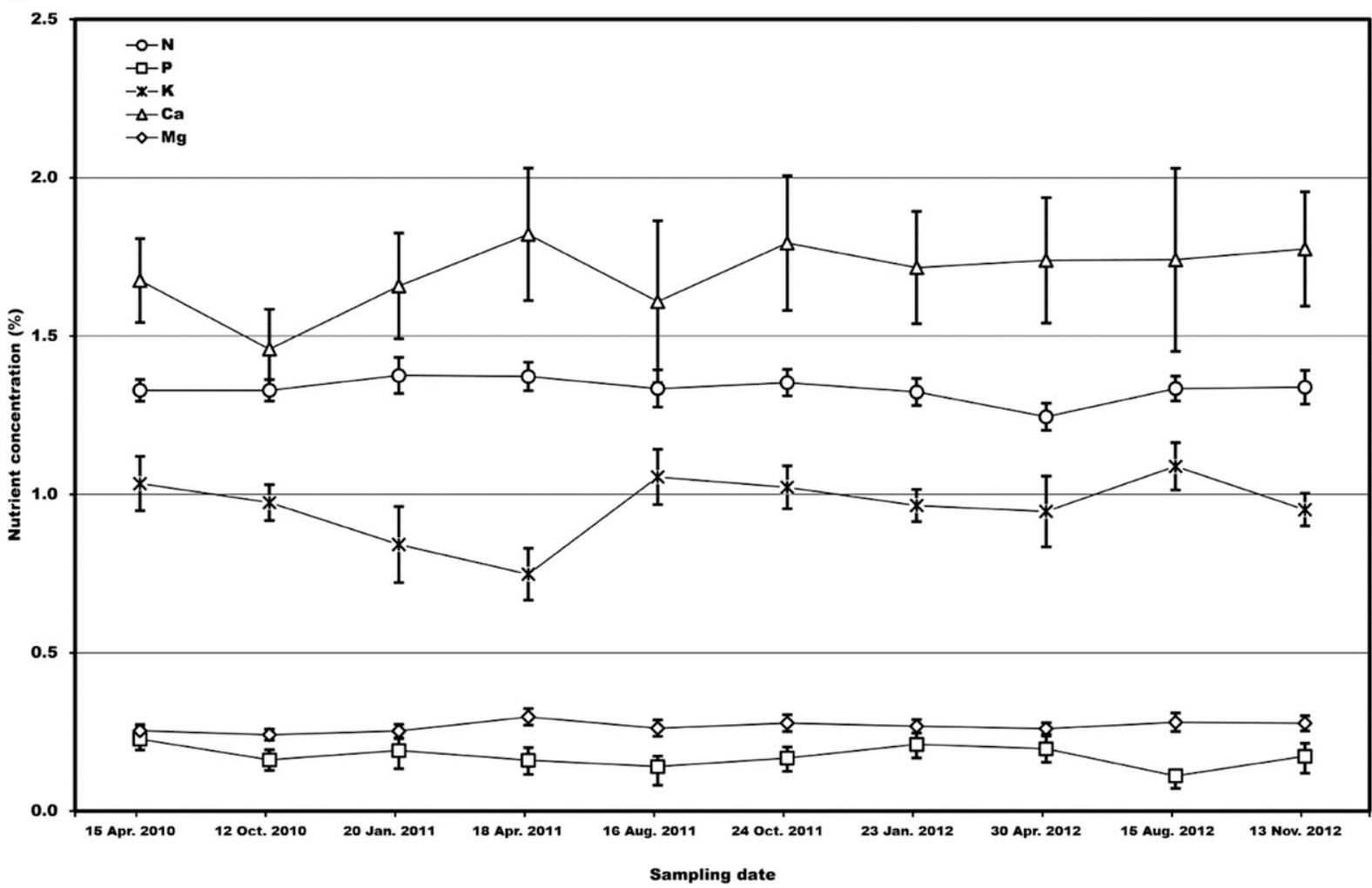

Fig. 1. Average leaf nutrient concentration of major elements [nitrogen $(\mathrm{N})$, phosphorous $(\mathrm{P})$, potassium $(\mathrm{K})$, calcium $(\mathrm{Ca})$, magnesium $(\mathrm{Mg})$ ] in 'Prolific' sapodilla grafted onto seedlings of 16 sapodilla rootstocks sampled (A) before and (B) after fertilization events. Values are the mean and SD of four replications and 16 rootstocks. 


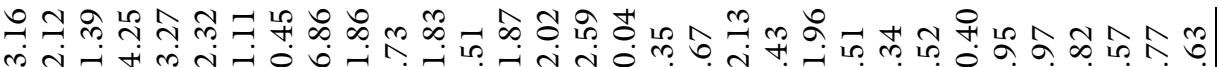

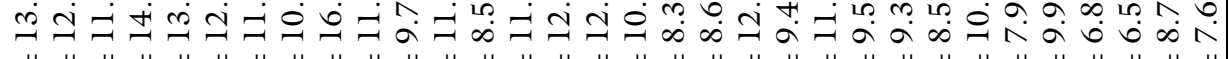

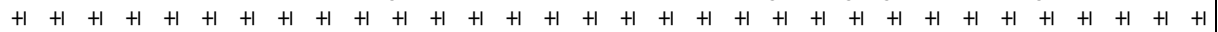

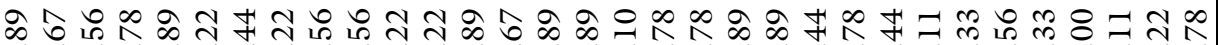

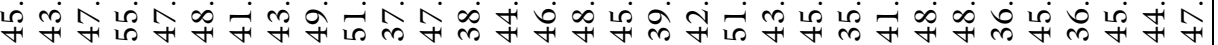

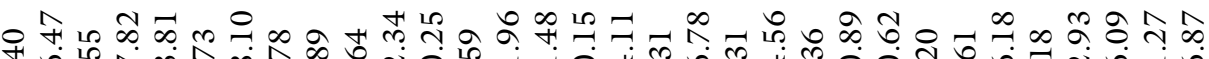
+

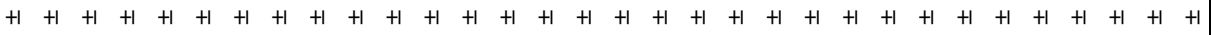

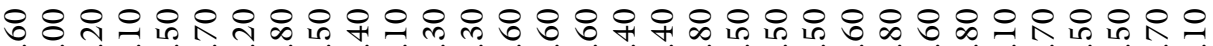
จำ

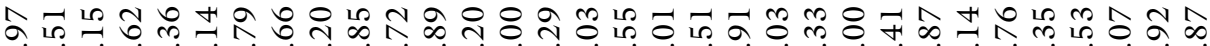

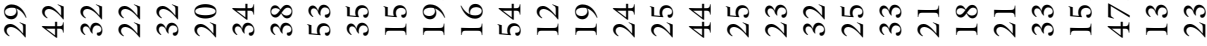

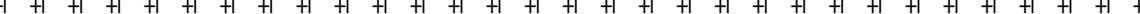

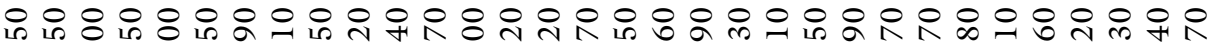

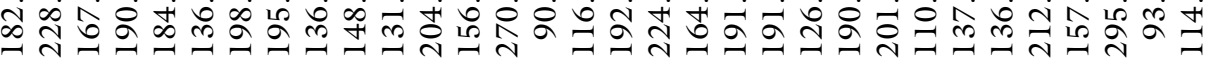

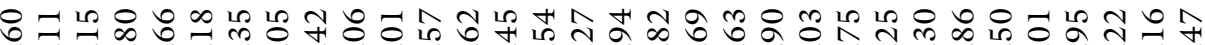
ம $+1+1+1+1+1+1+1+1+1+1+1+1+1+1+1+1+1+1+1+1+1+1+1+1+1+1+1+1+1+1+1+1$

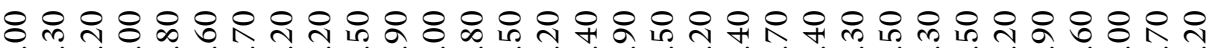

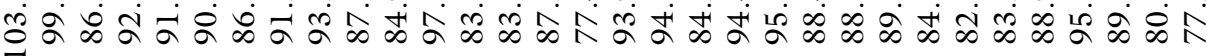

ง

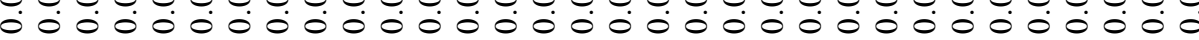

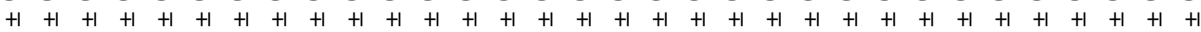

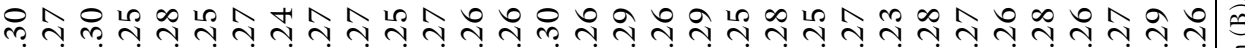
00000000000000000000000000000000

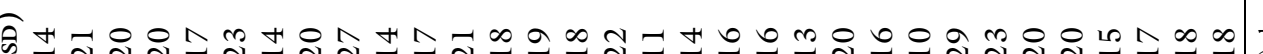

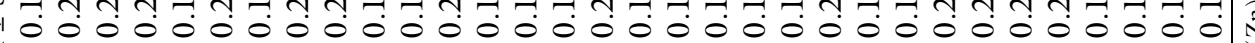

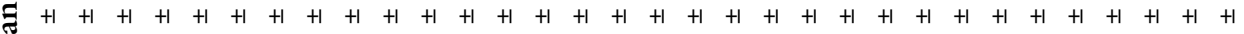

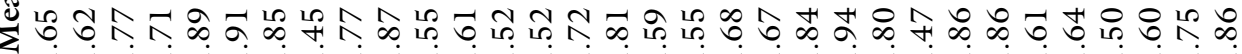

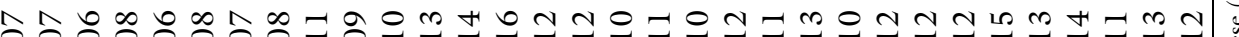
$\dot{0} 0 \dot{0} 0 \dot{0} 000000000000000000000000000$

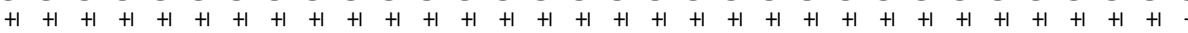

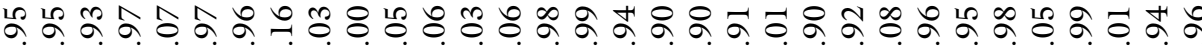
- ö0 ț 00000000000000000000000000000000

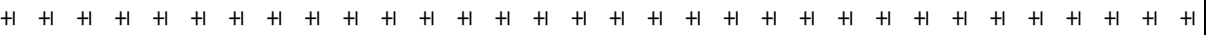

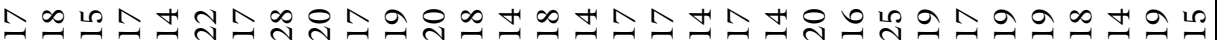
": \& t t t 00000000000000000000000000000000

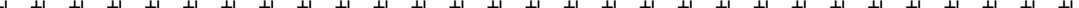

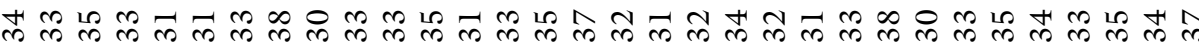
i-

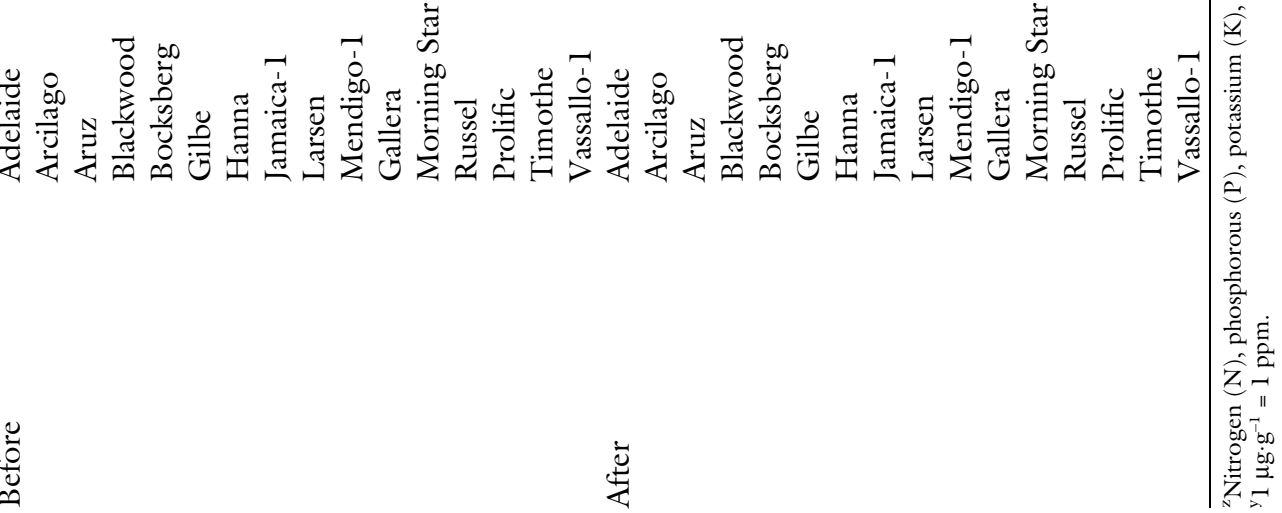



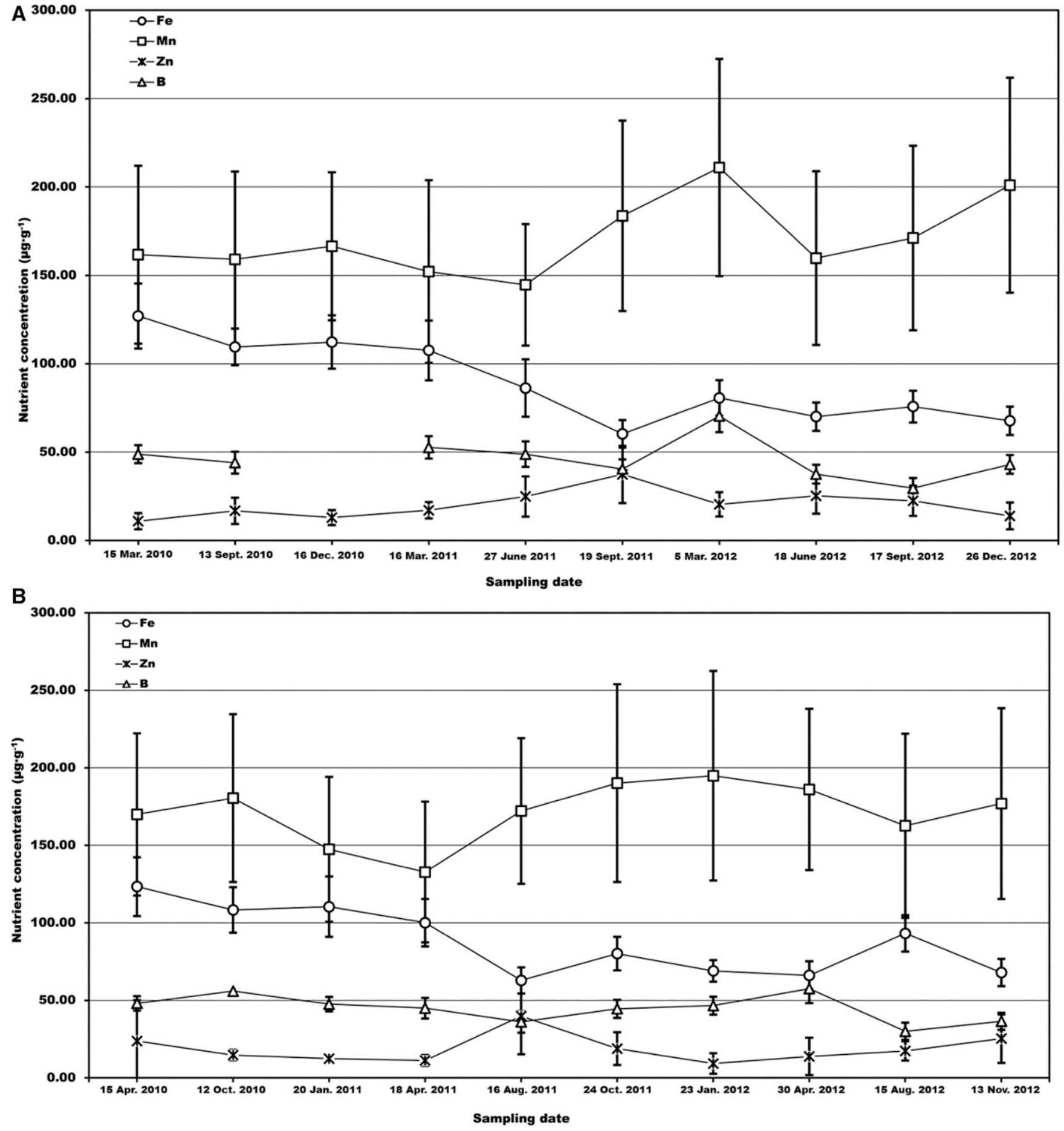

Fig. 2. Average leaf nutrient concentration of minor elements [iron (Fe), manganese (Mn), zinc (Zn), boron (B)] in 'Prolific' sapodilla grafted onto seedlings of 16 sapodilla rootstocks sampled (A) before and (B) after fertilization events. Values are the mean and SD of four replications and 16 rootstocks; $1 \mu \mathrm{g} \cdot \mathrm{g}^{-1}=1 \mathrm{ppm}$.

$1.38 \%$ and from $1.25 \%$ to $1.38 \%$, before and after fertilization events, respectively (Fig. IA and B). Similar seasonal values have been found in leaf litter of tropical fruits such as avocado, mango (Mangifera indica), and litchi (Litchi chinensis) (Murovhi et al., 2012). Average leaf P concentration ranged from $0.13 \%$ to $0.23 \%$ and from $0.11 \%$ to $0.23 \%$, before and after fertilization events, respectively. These values are within the $\mathrm{P}$ concentration range in leaf tissue of three apple (Malus sp.) cultivars grown in Brazil during fruit maturation (Nachtigall and Dechen, 2006) and mango (Prado, 2010). Average leaf $\mathrm{K}$ and $\mathrm{Ca}$ concentrations were more variable than the rest of the major elements (Fig. IA and B). Leaf $\mathrm{K}$ concentration before fertilization events ranged from $0.90 \%$ to $1.13 \%$ and from $0.75 \%$ to $1.09 \%$ after fertilization events. Average leaf $\mathrm{Ca}$ 
concentration ranged from $1.46 \%$ to $1.9 \%$ before fertilization and $1.46 \%$ to $1.82 \%$ after fertilization. Average leaf $\mathrm{Mg}$ concentration varied very little and averaged $0.26 \%$ before and after fertilization events, a similar concentration to that reported for mango by SalazarGarcia et al. (2014). Overall, leaf N, P, and $\mathrm{K}$ concentrations were higher in leaf tissue of trees grafted onto rootstock seedlings 'Jamaica-1' and 'Vasallo-1' before and after fertilization events (Table 3). Average N, P, and $\mathrm{K}$ in leaf tissue of these trees were $1.38 \%, 0.26 \%$, and $1.12 \%$, respectively, whereas it was $1.32 \%, 0.17 \%$, and $1.02 \%$, respectively, for the other rootstock seedlings.

Overall, minor elements (Fe, $\mathrm{Mn}, \mathrm{Zn}$, and B) showed more variation in leaf tissue concentration than major elements. During the last 33 months of the experimental period, average leaf Fe concentration ranged from 60 to $127 \mu \mathrm{g} \cdot \mathrm{g}^{-1}$ and from 63 to $123 \mu \mathrm{g} \cdot \mathrm{g}^{-1}$ before and after fertilization events, respectively (Fig. 2A and B). Average leaf $\mathrm{Mn}$ concentration ranged from 145 to $211 \mu \mathrm{g} \cdot \mathrm{g}^{-1}$ and from 133 to $195 \mu \mathrm{g} \cdot \mathrm{g}^{-1}$ before and after fertilization, respectively. The large variability in leaf Mn concentration at each sampling date was the result of trees grafted onto rootstock seedlings 'Arcilago' and 'Prolific' having higher leaf $\mathrm{Mn}$ concentration than those grafted onto other rootstock seedlings (Table 3). For example, average leaf Mn concentration for trees grafted onto rootstock seedlings 'Aruz', 'Gilbe', 'Larsen', 'Mendigo1', 'Gallera', 'Timothe', and 'Vasallol' was 132.3 and $126.3 \mu \mathrm{g} \cdot \mathrm{g}^{-1}$ before and after fertilization, respectively, whereas it averaged $249 \mu \mathrm{g} \cdot \mathrm{g}^{-1}$ for 'Arcilago' and $260 \mu \mathrm{g} \cdot \mathrm{g}^{-1}$ for 'Prolific'. Therefore, these two rootstock seedlings appear to be more efficient in taking up Mn than the former. Average leaf $\mathrm{Zn}$ concentration ranged from 13 to $37 \mu \mathrm{g} \cdot \mathrm{g}^{-1}$ before fertilization and from 9.25 to $39.8 \mu \mathrm{g} \cdot \mathrm{g}^{-1}$ after fertilization. Average leaf B concentration ranged from 29.5 to $70.3 \mu \mathrm{g} \cdot \mathrm{g}^{-1}$ and from 30 to $57 \mu \mathrm{g} \cdot \mathrm{g}^{-1}$ before and after fertilization, respectively. As with $\mathrm{Mn}$, leaf $\mathrm{Zn}$ concentration was higher in trees grafted onto 'Prolific', whereas leaf $\mathrm{B}$ was higher in trees grafted onto 'Blackwood' (Table 3).

To our knowledge, this is the first report of leaf nutrient concentration values in sapodilla.
Overall, leaf nutrient concentration values reported in this study are within sufficiency levels for other tropical fruit and nut crops such as mango, avocado, litchi, and guava (Psidium guajava) (Mills and BentonJones, 1996).

In conclusion, sapodilla 'Prolific' sapodilla was grafted onto 16 rootstock seedlings and evaluated during a 7-year harvest cycle. Rootstock seedlings 'Timothe', 'Vasallo-1', 'Larsen', and 'Aruz' had the highest mean number and yield of fruit. Both 'Timothe' and 'Vasallo-1' significantly out yielded the 'Prolific' rootstock seedling. Long-term leaf nutrient concentration for major and minor elements are reported for the first time for sapodilla and should serve as a reference for future nutritional studies with this crop.

\section{Literature cited}

Arevalo, L., R. Bautista, C. Saucedo, and T. Martinez. 2007. Cold storage and 1methylcyclopropene (1-MCP) applications on sapodilla fruits (Manilkara zapota (L.) P. Royen). Agrociencia 41:469-477.

Balerdi, C.F., J.H. Crane, and I. Maguire. 2013. Sapodilla growing in the Florida landscape. Univ. Florida, Florida Coop. Ext. Serv., Inst. Food Agr. Sci., Fact Sheet HS- 1 .

Balerdi, C.F. and P.E. Shaw. 1998. Sapodilla, sapota and related Fruit, p. 78 136. In: P.E. Shaw, H.T. Chan, and S. Nagy (eds.). Tropical and subtropical fruits. AgScience, Auburndale, FL.

Benton, J.J. 2001. Laboratory guide for conducting soil tests and plant analysis. CRC Press, Boca Raton, FL.

California Rare Fruit Growers, Inc. 1996. Sapodilla. 10 Feb. 2016. <http://www. crfg.org/pubs/ff/sapodilla.html>.

Campbell, R.J. and N. Ledesma. 2002. The sapodilla and green sapote's potential in tropical America. Proc. Interamer. Soc. Trop. Hort. 46:55-56.

Crane, J.H. and C.F. Balerdi. 2005. El chicosapote o nispero en Florida. Univ. Florida, Florida Coop. Ext. Serv., Inst. Food Agr. Sci., Document HS-1035.

Crane, J.H. and C.F. Balerdi. 2015. The chicosapote or sapodilla in Florida (in Spanish). Univ. Florida, Florida Coop. Ext. Serv., Inst. Food Agr. Sci., Document HS 1035.

Dixon, J. 2004. Avocado pollination best practice guidelines. 10 Feb. 2016. <http:// industry.nzavocado.co.nz/resources/ 4564727/Best_Practice_pollination_ avocado.pdf $>$.

Foss Tecator. 2002. The determination of nitrogen according to Kjeldahl using block digestion and steam distillation. Foss Tecator, Höganäs, Sweden.

Goenaga, R. and D. Jenkins. 2012. Yield and fruit quality traits of mamey sapote cultivars grown at two locations in Puerto Rico. HortTechnology 22:263-267.

Kader, A.A. 2009. Sapotes (sapodilla and mamey sapote): Recommendations for maintaining postharvest quality. $10 \mathrm{Feb}$. 2016. <http://postharvest.ucdavis.edu/ Commodity_Resources/Fact_Sheets/ Datastores/Fruit_English/? uid $=56 \&$ $\mathrm{ds}=798>$.

Mills, H.A. and J. Benton Jones, Jr. 1996. Plant analysis handbook II. Micromacro Publ., Athens, GA.

Morton, J.F. 1987. Fruits of warm climates. Media Inc., Greensboro, NC.

Mulvaney, R.L. 2007. Nitrogen: Inorganic forms, p. 1123-1184. In: D.L. Sparks (ed.). Methods of soil analysis. Part 3. Chemical methods. Soil Sci. Soc. Amer., Amer. Soc. Agron., Madison, WI.

Murovhi, N.R., S.A. Materechera, and S.D.S. Mulugeta. 2012. Seasonal changes in litter fall and its quality from three subtropical fruit tree species at Nelspruit, South Africa. Agrofor. Syst. 86:61-71.

Nachtigall, G.R. and A.R. Dechen. 2006. Seasonality of nutrients in leaves and fruits of apple trees. Sci. Agr. (Piracicaba, Braz.) 63493501.

Nelson, D.W. and L.E. Sommers. 2007. Total carbon, organic carbon and organic matter, p. 961-1010. In: D.L. Sparks (ed.). Methods of soil analysis. Part 3. Chemical methods. Soil Sci. Soc. Amer., Amer. Soc. Agron., Madison, WI.

Perkin-Elmer. 1994. Analytical methods for atomic absorption spectrometry. Perkin-Elmer, Norwalk, CT.

Prado, R.D.M. 2010. Phosphorous effects in the nutrition and growth of developing mango plants. J. Plant Nutr. 33:2041-2049.

Quijada, O., G. Castellano, R. Camacho, M. Matheus, and C. Gonzalez. 2005. Development and productivity of three sapodilla cultivars (Manilkara zapota Van Royen) in Zulia State, Venezuela. Proc. Interamer. Soc. Trop. Hort. 48:141-145.

Salazar-Garcia, S., G. Santillán-Valladolid, E.F. Hérnandez-Valdés, R. MedinaTorres, M.E. Ibarra-Estrada, and R. Gomez-Aguilar. 2014. Short term effect of site-specific fertilization in rainfed 
'Kent' and 'Tommy Atkins' mangos. Rev. Mex. Cienc. Agr. 5:645-659.

Shende, U.B. 1993. Studies on some aspects of postharvest handling and processing of sapota (Manilkara archas (Mill.) Forsberg) cv. Kalipatti. MSc Diss. Konkan Krishi Vidyapeeth, Dapoli, India.

Sumner, M.E. and W.P. Miller. 2007. Cation exchange capacity and exchange coefficients, p. 1201-1230. In: D.L. Sparks (ed.). Methods of soil analysis. Part 3. Chemical methods. Soil Sci. Soc. Amer., Amer. Soc. Agron., Madison, WI.
Tuell, J.K. and R. Isaacs. 2010. Weather during bloom affects pollination and yield of highbush blueberry. J. Econ. Entomol. 103:557-562.

Vasquez-Lopez, A., J.A. Mora-Aguilera, C. Nava-Diaz, and D. Teliz-Ortiz. 2012. Etiology and epidemiology of floral necrosis in sapote mamey (Pouteria sapota (Jacq.) H.E. Moore y Stearn) in Guerrero, Mexico. Rev. Fitotec. Mex. 35:325-332.
Velez-Colon, R., I. Beauchamp de Caloni, and S. Martinez-Garrastagu. 1989. Sapodilla (Manilkara zapota LV. Royen, Achras sapota Linn.) variety trials at southern Puerto Rico. J. Agr. Univ. Puert. Rico 73:255-264.

Wasielewski, J. and R.J. Campbell. 1999. Pruning and spraying sapodilla, mamey sapote and canistel for proper growth and production. Proc. Interamer. Soc. Trop. Agr. 43:139-142.

Winston, M.L. 1987. The biology of the honey bee. Harvard Univ. Press, Cambridge, MA. 